\title{
Population Genetic Structure of the Spotted Wolffish, Anarhichas minor, in the North Atlantic
}

\author{
Albert K. Imsland ${ }^{*}, a, b$, Karen Stensland ${ }^{b}$, Torild Johansen ${ }^{b}$, Nathalie Le Francois ${ }^{c}$, Simon Lamarre $^{c}$, \\ Gunnar Nævdal ${ }^{\mathrm{b}}$ and Atle Foss ${ }^{\mathrm{d}}$ \\ ${ }^{a}$ Akvaplan-niva, Iceland Office, Akralind 4, 201 Kópavogi, Iceland \\ ${ }^{b}$ Department of Biology, University of Bergen, High Technology Centre, 5020 Bergen, Norway \\ ${ }^{c}$ Département de Biologie, Laboratoire de Biologie évolutive, Université du Québec á Rimouski, Québec, Canada \\ ${ }^{d}$ Akvaplan-niva, Bergen Office, Pb. 2026 Nordnes, N-5817 Bergen, Norway.
}

\begin{abstract}
The genetic population structure of spotted wolffish Anarhichas minor (Olafsen) in the North Atlantic was investigated by allozyme electrophoresis and by PCR based RFLP variation in mtDNA. Samples were collected from five sites distributed across the North Atlantic and from second generation Norwegian broodstock. The present data demonstrates that significant differences exist between almost all sampling sites, indicating biologically different groups of individuals, and thus the existence of different management populations of spotted wolffish in the North Atlantic. Overall, the data indicated that isolation by distance is weak among spotted wolffish at the geographic scale investigated in this study, suggesting that gene flow between neighbouring spotted wolffish populations is low. The present study demonstrates a high level of geographic population structure between the western Atlantic, middle and eastern Atlantic and Baltic Sea, and thus, the findings should be useful in devising overall management and conservation strategies for the species.
\end{abstract}

\section{INTRODUCTION}

Marine environment is considered to be highly dispersive and, thus, marine species are often supposed to be poorly genetically structured (Ward JFB 1994) [1]. However, given the relatively high species diversity observed in oceans, it can be asserted that dispersal may be lower than commonly expected (Charrier MPE 2006) [2]. The global level of genetic differentiation within species results from a complex equilibrium between structuring factors (water fronts, isolation by distance, hydrodynamic eddies or gyres favouring larval retention, discrete spawning units, and phylopatric behaviour) and homogenising factors (long larval pelagic phase, migratory behaviour of adults, high connectivity of marine environment) (Charrier MPE 2006) [2]. The spotted wolffish (Anarhichas minor) is an arctic-boreal bottomdwelling species, distributed in the North Atlantic and the Barents Sea mainly in waters with temperatures ranging from $-1^{\circ} \mathrm{C}$ to $7{ }^{\circ} \mathrm{C}$ and at depths from $25-550 \mathrm{~m}$ (Østvedt FSH 1963) [3]. Spotted wolffish are sedentary and mostly solitary in habit, except during mating. In nature the species displays rather slow growth (Østvedt FSH 1963 [3] Templeman JNAFS 1986) [4], and maturation does not occur until after 7-9 years. It has internal fertilization and the eggs $(5-6 \mathrm{~mm}$ diameter) are collected in a ball and probably guarded by the male until hatching, which occurs after approximately 800$1000 \mathrm{D}^{\circ}$ (day-degrees) (Falk-Petersen AR 2003) [5]. The larvae hatch as well developed individuals $(20-24 \mathrm{~mm})$, live pelagically for several weeks and settle in benthic environments at $4-6 \mathrm{~cm}$. Tagging and recapture studies of wolffishes indicate that migrations generally are short, but long distance

*Address correspondence to this author at the Akvaplan-niva, Iceland Office, Akralind 4, 201 Kopavogur, Iceland; Tel: 0035456258 01; Fax: 00354 56458 01; Email: imsland@ vortex.is or albert.imsland@akvaplan.niva.no migrations have been observed (Østvedt FSH 1963 [3] Templeman JNAFS 1984 [6]). The maximum migration distance of spotted wolffish observed in the Barents Sea, along the Norwegian coast and around Bear Island was less than 300 nautical miles (nm), with an average of $5 \mathrm{~nm}$ each day (Østvedt FSH 1963) [3]. In the Newfoundland area, spotted wolffish seem to be more stationary than common wolffish (Templeman JNAFS 1984) [6]. However, the population genetics in spotted wolffish has up to now not been studied with molecular methods, and morphometric and morphological studies are contrasting (Barsukov SI 1959 [7] Østvedt FSH 1963 [3] Templeman JNAFS 1986 [4]).

In the present study two genetic methods (i.e. allozymes and RFLP of ND3/ND4 gene complex in mtDNA) were applied to investigate the population genetics of spotted wolffish. The current study is, therefore, intended to provide information on population structure of spotted wolffish throughout its entire range. This should aid in the management and conservation of the species.

\section{MATERIALS AND METHODOLOGY}

\section{Sample Collection and Preservation}

Adult spotted wolffish were sampled from Canada, Iceland, Tromsøflaket and the Barents Sea (Table 1, $\mathrm{n}=298$ ).

In order to study possible genetic drift in hatchery practise a sample of second generation Norwegian broodstock (parents caught off Northern Norway) was also included in the study. The Canadian fish where caught mainly at the Bauge bank near Anticosti Island, in the Gulf of St. Lawrence. The average weight and length for the Canada CAM (Centre Aquacole Marin de Grand-Rivière, Québec, Canada) sample were less than for the Canada IML (Maurice Lamontagne Institute of Department of Fisheries and Oceans, Qué- 
Table 1. Overview of Spotted Wolffish Samples Collected for the Present Study, with Information on Geographical Areas, Station Position, Date, Sampling Depth, Number of Individuals (n) and Tissue Type Sampled. All Fish were Caught by Longline Except the Icelandic Wolffish that were Caught by Trawl

\begin{tabular}{|c|c|c|c|c|c|c|}
\hline Geograph. Area & Position & Date & Sample. Depth (m) & $\boldsymbol{n}$ & Allozyme & mtDNA \\
\hline \hline Canada CAM & $49^{\circ} 13^{\prime} \mathrm{N} 59^{\circ} 30^{\prime} \mathrm{W}$ & April 2004 & $100-200$ & 28 & Muscle & Fin clip \\
\hline Canada IML & $48^{\circ} 52^{\prime} \mathrm{N} 61^{\circ} 21^{\prime} \mathrm{W}$ & Jan. 2004 & $100-200$ & 25 & Muscle & Fin clip \\
\hline Iceland & $64^{\circ} 50^{\prime} \mathrm{N} 11^{\circ} \mathrm{W}$ & Dec. 2003 & $270-320$ & 95 & Muscle & Muscle, liver \\
\hline Troms $\varnothing f l a k e t$ & $71^{\circ} 26^{\prime} \mathrm{N} 18^{\circ} 49^{\prime} \mathrm{E}$ & Oct. 2003 & $250-300$ & 123 & Muscle clip \\
\hline Barents Sea & $74^{\circ} \mathrm{N} 33^{\circ} \mathrm{E}$ & Aug. 2005 & $300-350$ & 20 & Fin clip \\
\hline Norw. broodst. & $71^{\circ} \mathrm{N} 18^{\circ} \mathrm{E}$ & July 2005 & $150-300$ & 27 & Muscle & Gill \\
\hline
\end{tabular}

CAM; Centre Aquacole Marin de Grand-Rivière, Québec, Canada. IML; Maurice Lamontagne Institute of Department of Fisheries and Oceans, Québec, Canada.

Norw. broodst.; Norwegian broodstock (second generation), parents caught near Tromsøflaket.

bec, Canada) sample and were collected in two seasons so these samples were not pooled in the study. Samples from the Barents Sea were obtained from wild caught fish held in captivity at Tomma Marinfisk (Nordland, Norway). The Barents Sea sample was only collected for mitochondrial DNA analysis as merely fin-clips were collected. For the allozyme analysis, the muscle tissue was collected on microtest plates and stored at $-80^{\circ} \mathrm{C}$. Tissue for the mtDNA analyses were fixed in $96 \%$ ethanol.

\section{Allozyme Analysis}

A total of 11 specific enzymes were tested during the initial survey to identify allelic variation analysed by starch gel electrophoresis in three buffer systems as described by Reisegg and Jørstad (FR 1984) [8]. Three enzymes, isocitrate dehydrogenase (IDH), maltate dehydrogenase (MDH), and phosphoglucose isomerase (PGI) had sufficient activity to be scored reliably and was found polymorphic by Histidine/Tricitrate, $\mathrm{pH}=7.0$ starch gel electrophoresis.

\section{RFLP analysis of mtDNA}

DNA was extracted by using commercially available Qiagen DNeasy Tissue Kit (Quiagen Nordic, Solna, Sweden). Mitochondrial DNA gene complex ND3/ND4 was PCR amplified by primers developed for Salmo sp. and Sebastes sp. (Thomas JME 1989 [9] Gharrett FB 2001 [10]). PCR was carried out using previously published reaction mixtures and temperature cycles (Gharret FB 2001) [10]. Preliminary tests with 24 to 26 test individuals chosen to represent samples from all areas were performed using a number of 14 restriction enzymes were performed for ND3/ND4. Two restriction enzymes; AluI and Sau3AI were polymorphic and were applied for all the remaining individuals.

\section{Data Analysis}

Allozyme allele frequencies and observed and expected heterozygosity calculations were performed in BIOSYS-2 (Swofford DGD 1997) [11]. Observed genotypic proportions were tested for agreement with expected Hardy-Weinberg equilibrium proportions using a log likelihood ratio $G$ test. MtDNA haplotype patterns for each enzyme were given an alphabetical (A, B, etc.) code, with haplotype A being the most common, and the remainder ranked in the order in which they were found for each restriction enzyme. Composite restriction enzyme patterns were then given a numerical code (1-14) to facilitate data handling. Data were converted into a binary format, coding restriction sites as presence/absence (1/0). Compound haplotype frequencies and the haplotype frequencies were individually calculated, and unique and shared haplotypes found. Variation within samples was estimated by nucleotide diversity $(\pi)$ and haplotype diversity (h) (Nei MEG 1987) [12].

Pairwise $\mathrm{F}_{\mathrm{ST}}$ values were calculated using the Arlequin v3.01 (Exoffier EBO 2005) [13]. Significance of $F_{S T}$ values was determined using a non-parametric permutation of individuals between the different sampling sites.

To test the hypothesis of isolation-by-distance, correlation between pairwise $\mathrm{F}_{\mathrm{ST}}$ and geographic distances between locations was analysed using the Mantel test (Mantel CR 1967) [14] as implemented in POPTOOLS(available at http: //www.dwe.csiro.au/vbc/poptools) and significance was tested by 10000 permutations. Geographic distances were measured as the minimum distance between each pair of samples. A principal component analysis (Johnson AMSA 1992) [15] was performed and the factor loadings for all six sampling sites presented in a two-dimensional plot. Separate analyses were performed for allozymes and mtDNA data. Correction for multiple tests of overall significance values was carried out using the sequential Bonferroni procedure (Rice ATST 1989) [16].

\section{RESULTS}

\section{Allozyme Polymorphism}

The PGI, IDH and the MDH enzyme showed polymorphism with two, three, and three alleles respectively. The PGI-2*100 allele frequencies varied between sites, from 0.38 (Canada IML) to 0.96 (Iceland) (Table 2).

In the Canada IML site a rare allele PGI-2*200 was found in 10 of 21 individuals analysed. A G test showed significant deviation from Hardy-Weinberg's equilibrium in the PGI-2* locus in the Canadian samples (Table 2). The frequency of the most common allele IDH*100 varied from 0.66 (Canada CAM) to 0.85 (Iceland and Tromsøflaket). Unfortunately, the Canada IML could not be read because of blurred enzyme patterns. The most common allele, MDH$3 * 100$, varied in frequency from 0.79 (Tromsøflaket) to 0.90 
Table 2. Summary Statistics for the for Three Allozyme Loci of Spotted Wolffish Samples from Five Locations in the North Atlantic: Allele Frequencies, Number of Individual Screened ( $n$ ), and $G$ Test Statistic for Departure from Hardy-Weinberg are Shown for Each Locus at Each Site. Observed and Expected Heterozygosity $\left(H_{o}, H_{e}\right)$ are Shown for All Loci Combined for Each Sampling Site

\begin{tabular}{|c|c|c|c|c|c|}
\hline $\begin{array}{l}\text { Locus/ } \\
\text { Alleles }\end{array}$ & $\begin{array}{c}\text { Canada } \\
\text { CAM }\end{array}$ & $\begin{array}{l}\text { Canada } \\
\text { IML }\end{array}$ & Iceland & $\begin{array}{c}\text { Tromsø- } \\
\text { Flaket }\end{array}$ & $\begin{array}{l}\text { Norw. } \\
\text { Brood. }\end{array}$ \\
\hline \multicolumn{6}{|l|}{ PGI-2* } \\
\hline 100 & 0.73 & 0.38 & 0.96 & 0.96 & 0.91 \\
\hline 130 & 0.27 & 0.14 & 0.04 & 0.04 & 0.09 \\
\hline 200 & & 0.48 & & & \\
\hline$n$ & 28 & 21 & 91 & 123 & 27 \\
\hline$G$ & $4.15^{*}$ & $14.83 * * *$ & 0.12 & 0.20 & 2.01 \\
\hline \multicolumn{6}{|l|}{$I D H^{*}$} \\
\hline 100 & 0.66 & & 0.85 & 0.84 & 0.46 \\
\hline 130 & 0.34 & & 0.15 & 0.17 & 0.54 \\
\hline$n$ & 28 & 0 & 95 & 118 & 27 \\
\hline$G$ & 0.14 & & 1.09 & 0.39 & 0.89 \\
\hline \multicolumn{6}{|l|}{$M D H-3 *$} \\
\hline 70 & 0.11 & 0.10 & 0.15 & 0.22 & 0.06 \\
\hline 100 & 0.89 & 0.90 & 0.85 & 0.78 & 0.94 \\
\hline$n$ & 27 & 25 & 92 & 123 & 27 \\
\hline$G$ & 0.35 & 0.24 & 1.02 & 0.15 & 0.06 \\
\hline$H_{o}$ & 0.288 & 0.098 & 0.218 & 0.226 & 0.210 \\
\hline$H_{e}$ & 0.344 & 0.269 & 0.200 & 0.232 & 0.262 \\
\hline
\end{tabular}

(Canada IML). Genotype distributions for the IDH and MDH enzymes did not deviate from expected HardyWeinberg's equilibrium for any of the calculated sites. The direct count of the mean heterozygosity varied from 0.098 (Canada IML) to 0.288 (Canada CAM), while the HardyWeinberg expected heterozygosity varied from 0.200 (Iceland) to 0.344 (Canada CAM). Deviation between observed and Hardy-Weinberg expected heterozygosity was largest in the Canadian IML sample (0.171).

\section{Mitochondrial DNA Polymorphism}

Five haplotypes (A-E) for AluI, and six (A-F) for Sau3AI were detected, and a total of 14 composite haplotypes was found for 133 individuals (Table 3). Haplotype 2 (AB) was the most common, present in $27.6 \%$ of individuals, while the next most frequent (haplotype 3, AC) was present in $22.4 \%$ of individuals. In all, 5 haplotypes occurred only once. Average haplotype diversity within populations was high $(\mathrm{h}=$ 0.65 ), and nucleotide diversity was low (average $\pi=0.0128$, Table 3).
Table 3. Composite Haplotypes Frequency and Diversity Estimates of the Mitochondrial DNA ND3/ND4 in Spotted Wolffish from Five Sampling Sites in the North Atlantic, and from Second Generation Norwegian Broodstock. The First Letter in the Haplotype is for AluI and the Second is for Sau3A

\begin{tabular}{|c|c|c|c|c|c|c|c|}
\hline $\begin{array}{c}\text { Comp. } \\
\text { Haplo- } \\
\text { type }\end{array}$ & $\begin{array}{c}\text { Haplo- } \\
\text { type }\end{array}$ & $\begin{array}{c}\text { Can. } \\
\text { CAM }\end{array}$ & $\begin{array}{c}\text { Can. } \\
\text { IML }\end{array}$ & $\begin{array}{c}\text { Ice- } \\
\text { land }\end{array}$ & $\begin{array}{c}\text { Tromsø } \\
\text { Flaket }\end{array}$ & $\begin{array}{c}\text { Barents } \\
\text { Sea }\end{array}$ & $\begin{array}{c}\text { Norw. } \\
\text { Brood. }\end{array}$ \\
\hline \hline H1 & AA & 5 & & 3 & & 0 & 0 \\
\hline H2 & AB & 8 & 4 & 13 & 12 & 0 & 8 \\
\hline H3 & AC & 1 & 5 & 8 & 3 & 13 & 0 \\
\hline H4 & BB & 2 & 1 & 4 & 4 & 0 & 2 \\
\hline H5 & BA & 7 & 1 & 1 & 0 & 0 & 1 \\
\hline H6 & BC & 0 & 7 & 2 & 0 & 1 & 0 \\
\hline H7 & CB & 0 & 1 & 0 & 0 & 0 & 0 \\
\hline H8 & AD & 0 & 0 & 0 & 0 & 1 & 0 \\
\hline H9 & AE & 0 & 0 & 3 & 0 & 0 & 5 \\
\hline H10 & AF & 0 & 0 & 0 & 1 & 0 & 0 \\
\hline H11 & BE & 0 & 0 & 2 & 0 & 0 & 0 \\
\hline H12 & BF & 0 & 0 & 1 & 0 & 0 & 0 \\
\hline H13 & EC & 0 & 0 & 1 & 0 & 0 & 0 \\
\hline H14 & ED & 0 & 0 & 1 & 0 & 0 & 0 \\
\hline h & & 0.76 & 0.78 & 0.83 & 0.60 & 0.26 & 0.65 \\
\hline s.e. \pm & & 0.04 & 0.06 & 0.04 & 0.10 & 0.15 & 0.09 \\
\hline$\pi$ & 0.015 & 0.015 & 0.018 & 0.010 & 0.005 & 0.014 \\
\hline$n$ & 23 & 19 & 39 & 16 & 19 & 17 \\
\hline
\end{tabular}

$\mathrm{h}=$ haplotype diversity, s.e. $=$ standard error, $\pi=$ nucleotide diversity, $n=$ number of specimens analysed.

\section{Genetic Differentiation Among Spotted Wolffish Popula-} tions

For the allozyme data pairwise $\mathrm{F}_{\mathrm{ST}}$ values varied from 0 (Troms $\varnothing$ flaket-Iceland) to 0.40 (Canada IML-Iceland, Table 4) and were significant between all sites except between the Iceland and Tromsøflaket sites.

Table 4. Pair-Wise $\boldsymbol{F}_{\mathrm{ST}}$ Estimates for the Allozyme Data. Statistically Significant $\boldsymbol{F}_{\mathrm{ST}}$ Values After Correction for Multiple Tests are Given in Bold

\begin{tabular}{|c|c|c|c|c|c|}
\hline Site & $\begin{array}{c}\text { Can } \\
\text { CAM }\end{array}$ & $\begin{array}{c}\text { Can } \\
\text { IML }\end{array}$ & $\begin{array}{c}\text { Ice } \\
\text { land }\end{array}$ & $\begin{array}{c}\text { Troms } \varnothing \\
\text { Flaket }\end{array}$ & $\begin{array}{c}\text { Norw. } \\
\text { Brood. }\end{array}$ \\
\hline \hline $\begin{array}{c}\text { Canada CAM } \\
\text { Canada IML } \\
\text { Iceland }\end{array}$ & & $\mathbf{0 . 1 9}$ & $\mathbf{0 . 1 0}$ & $\mathbf{0 . 1 0}$ & $\mathbf{0 . 0 5}$ \\
\cline { 3 - 6 } $\begin{array}{c}\text { Tromsøflaket } \\
\text { Norw. broodstock }\end{array}$ & & $\mathbf{0 . 4 0}$ & $\mathbf{0 . 3 8}$ & $\mathbf{0 . 3 2}$ \\
\cline { 3 - 6 } & & & & $\mathbf{0 . 1 9}$ \\
\cline { 3 - 6 }
\end{tabular}


Pairwise $\mathrm{F}_{\mathrm{ST}}$ tests of population genetic differentiation were significant for the mtDNA data (Table 5). Pairwise $F_{S T}$ values varied from 0.03 (Tromsøflaket-Iceland) to 0.54 (Norw. broodstock-Barents Sea, Table 5).

Table 5. Pair-wise $\boldsymbol{F}_{\mathrm{ST}}$ Estimates for mtDNA Data from Spotted Wolffish. Statistically Significant $F_{\text {ST }}$ Values After Correction for Multiple Tests are Given in Bold

\begin{tabular}{|c|c|c|c|c|c|c|}
\hline Site & $\begin{array}{l}\text { Can. } \\
\text { CAM }\end{array}$ & $\begin{array}{l}\text { Can } \\
\text { IML }\end{array}$ & $\begin{array}{l}\text { Ice- } \\
\text { land }\end{array}$ & $\begin{array}{l}\text { Tromsø } \\
\text { Flaket }\end{array}$ & $\begin{array}{c}\text { Barents } \\
\text { Sea }\end{array}$ & $\begin{array}{l}\text { Norw. } \\
\text { Brood. }\end{array}$ \\
\hline Canada CAM & & 0.14 & 0.05 & 0.12 & 0.44 & 0.10 \\
\hline Canada IML & & & 0.05 & 0.16 & 0.29 & 0.18 \\
\hline Iceland & & & & 0.03 & 0.28 & 0.05 \\
\hline Tromsøflaket & & & & & 0.49 & 0.03 \\
\hline Barents Sea & & & & & & 0.54 \\
\hline Norw. broodstock & & & & & & \\
\hline
\end{tabular}

In general the highest $\mathrm{F}_{\mathrm{ST}}$ values were seen for the Barents Sea sample in comparison with other sampling sites. The principal component analysis of allozymes and mtDNA data (Fig. 1) revealed similar picture for both data sets as the Canada IML and the Barents Sea (only mtDNA data) were the most distinct sites. It is notable that the two Canadian sample sites are found to be genetically distinct.

\section{Isolation by Distance}

The Mantel test performed revealed a lack of correlation between geographic distances between locations and pairwise $\mathrm{F}_{\mathrm{ST}}(\mathrm{mtDNA}$ data, $\mathrm{r}=-0.083, \mathrm{p}=0.392$, allozyme data, $r=0.09, p=0.598)$. Therefore, spotted wolffish is characterised by a lack of isolation by distance in the North Atlantic Ocean.

\section{DISCUSSION}

This study demonstrated significant population structure in spotted wolffish from across the species range, with especially large differences occurring between the Barents Sea and other Atlantic samples. Unfortunately, allozyme data were not available for the Barents Sea sample so firm conclusion about the degree of distinctiveness between the Barents Sea and the other samples is premature. However, population structure was also identified within the Atlantic basin itself with significant differences found between sampling sites for both methods used in this study. Significant distinct populations in the North Atlantic have been suggested for a number of demersal species like tusk Brosme brosme (Johansen JFB 1995) [17]; Atlantic halibut (Foss JFB 1998) [18]; Atlantic cod, Gadus morhua L. (Jónsdóttir FR 2003 [19] O'Leary JFB 2007) [20] and redfish Sebastes viviparous (Johansen JFB 1995) [17], and several mechanisms have been suggested to explain the observed levels of population divergence. These mechanisms include reproductive isolation (Foss JFB 1998) [18], different gene pools (Johansen JFB 1995) [17], and isolation by distance (O'Leary JFB 2007) [20].

For the mtDNA data samples from Tromsøflaket and from second generation Norwegian broodstock appeared
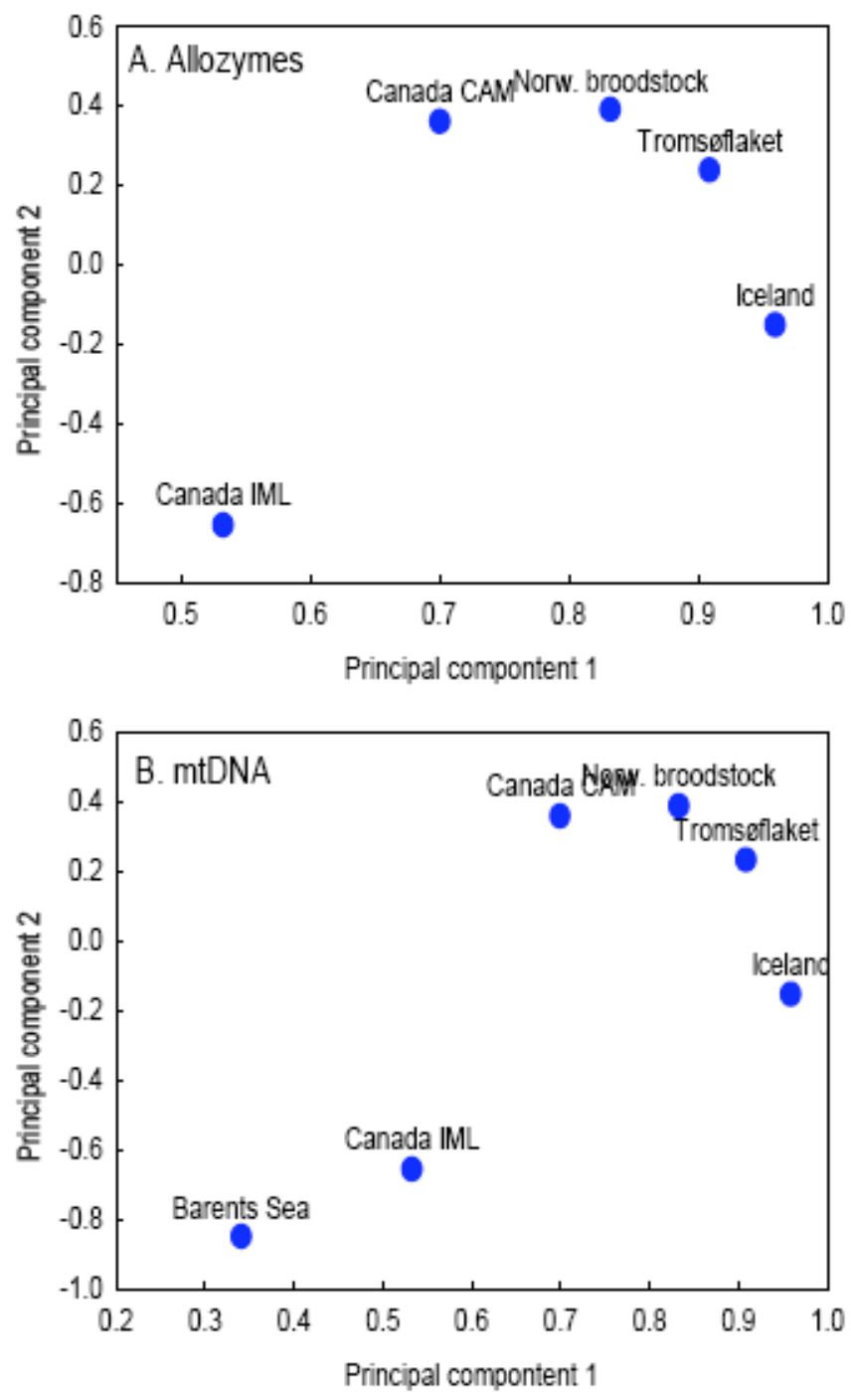

Fig. (1). Principal component scatter plots derived from analyses of allozyme frequency (A) and from mtDNA data (B) in six sample units of spotted wolffish.

genetically similar indicating that hatchery management had not caused abrupt genetic drift as seen in other species when comparing wild and farmed fish (Coughlan JFB 1998) [21]. However, this conclusion should be modified by the fact that both samples are significantly differentiated at allozyme markers. In particular these samples show substantial differences in allele frequencies at two of the three allozymes (IDPH and MDH-3). Thus, given the fact that allozymes might be sensitive to selection (Marchand MEPS 2003) [22], we can suppose that the genetic variability of the Norwegian broodstock has been shaped by substantial selective pressures induced by hatchery practices, but that is only seen in the allozyme data due to possible selection on these markers.

Overall, the present results indicated that isolation by distance (IBD) is weak among spotted wolffish at the geographic scale investigated in this study. IBD should reflect a balance between genetic drift and gene flow, with the former increasing and the latter decreasing genetic divergence (Hutchison E 1999) [23]. Moreover, IBD should be maximal at equilibrium between genetic drift and gene flow, which 
may take a considerable length of time to develop (Crispo CG 2005) [24]. Barriers to dispersal and hence gene flow are likely to disrupt IBD. These barriers can be either physical (e.g. Castric G 2001) [25] or behavioral (e.g. Gold MB 1999) [26]. If no such barriers appear likely, some authors conclude that populations not exhibiting IBD have been too recently colonized or have been influenced by Pleistocene glaciers (Crispo CG 2005) [24]. Other factors, such as heterogeneity of spawning habitat or gyral retention of larvae (Hansen ICES 1986) [27], may drive population differentiation at both geographically large and more localized scales. The wolffishes in general are considered a slow-moving, inactive fishes, and migration studies of spotted wolffish indicate predominantly short migration routes (Østvedt FSH 1963 [3] Templeman JNAFS 1984) [4] which are suggested to be spawning-related. The weak IBD found in the present study may suggest gene flow between neighbouring spotted wolffish populations is low, which fits with the sedentary life-history of the spotted wolffish.

Most samples were in Hardy-Weinberg equilibrium for all loci, which suggests that each sample is representative of a population. However, the PGI-2* locus at the Canadian sample sites (IML/CAM) deviated significantly from the Hardy-Weinberg's equilibrium (HWE). Disequilibrium at the Canada IML site can be explained by that almost $50 \%$ of the fish caught in IML was homozygote for the rare PGI$2 * 200$ allele (Table 2). One explanation of this might be linked to low population size of spotted wolffish in the Gulf of St. Lawrence, but two other hypotheses are possible: (1) the mixture in the same sample of individuals stemming from genetically differentiated units (Walhund effect) or (2) selection processes. It is important to keep in mind that allozymes can be submitted to strong selective pressure (Merchand MEPS 2003) [22]. Random genetic drift may also cause a sudden increase in rare alleles (Falconer IQG 1989) [28]. Northern and spotted wolffish were listed as threatened by the Canadian government in the Species at Risk Act (SARA) in 2001. It is estimated that the spotted wolffish stock within the Gulf of St. Lawrence has declined 87-94\% from 1980 to 1994 (Anon. 2002) [29]. However, the loss of heterozygosity and increase in rare alleles is observed only in one of the two Canadian populations (IML), whereas the CAM sample displays the highest level of heterozygosity in the overall data set. Thus this result does not support very well the hypothesis of low population size: it seems difficult to think that the reduction of population size of spotted wolffish in the Gulf of St. Lawrence has impacted the genetic variability only of a fraction of the population (IML) but not of the other (CAM). Moreover, the relatively high level of haplotype diversity for both Canadian samples $(\mathrm{h}=0.76-0.78)$ observed with mtDNA data does not provide evidence of a reduced genetic variability due to a strong genetic drift as mtDNA is potentially more sensitive to drift than nuclear markers (e.g. Hansen E 1996) [30].

It is notable that the present data indicated distinctiveness of the two Canadian samples. They were sampled in the same geographic area but in separate seasons and the specimens in the Canada IML sample were larger. Both CAM and IML samples show similar allele frequencies at MDH-3 locus and the IDPH marker was not scorable for the IML sample. Thus the significant genetic structure observed between these samples at allozyme markers is only driven by $P G I-2 *$ locus and more precisely by the allele PGI- $2 * 200$, that is found only in the IML sample. Moreover, it is particularly striking to observe (1) that $50 \%$ of the fish caught in IML were homozygote for this allele PGI- $2 * 200$ and (2) the relative proportion of the alleles PGI- $2 * 100$ and PGI- $2 * 130$ are similar in both CAM and IML samples if we exclude the allele PGI- $2 * 200$ in IML. To explain this we propose two distinct hypotheses:

(1) Individuals form the IML sample were larger than those from the CAM one and thus we can suppose that the IML fish were older. Therefore, the genetic differentiation observed between Canadian samples might be interpreted as a temporal genetic variability between year-classes due to strong differential selection processes between year-classes. Notably, such a temporal structure may be due to a chaotic genetic patchiness, as described by Larson (CALCOFI 1999) [30].

(2) More probably, the genetic differentiation between the Canadian samples might be due to the presence in the IML sample of individuals from another wolffish species. The possibility of hybrids in the sample seems highly unlikely given the fact that most of the fish seem to be homozygote for the rare allele PGI$2 * 200$ while hybrids should be heterozygote for alleles stemming from other wolffish species. It should be able to test this last hypothesis by genotyping a few individuals from each wolffish species recorded in the Gulf of St. Lawrence at the three different allozymes, to detect the presence of the allele PGI$2 * 200$ in these species.

\section{CONCLUSIONS}

Allozyme and mitochondrial DNA RFLP analysis of spotted wolffish collected from across the North Atlantic revealed genetic substructure of the species across its range. In particular the results indicate a clear differentiation between the Barents Sea population and other Atlantic population units and to a lesser extent between west and east Atlantic population units.

\section{ACKNOWLEDGEMENTS}

The study was financed by the Research Council of Iceland (Contract no: 031000004) and NORA (Nordic Atlantic Co-operation). We thank Lars Olav Sparboe and Sindri Sigurðsson for their kind assistance in relation to sampling of spotted wolffish, and Solveig Thorkildsen for technical assistance during the laboratory work.

\section{REFERENCES}

[1] Ward RD, Woodward M, Skibinski DOF. A comparison of genetic diversity levels in marine, freshwater, and anadromous fishes. $\mathrm{J}$ Fish Biol 1994; 44: 213-32.

[2] Charrier G, Chenel T, Durand JD, Girard M, Quiniou L, Laroche J. Discrepancies in phylogeographical patterns of two European anglerfishes (Lophius budegassa and Lophius piscatorius). Mol Phyl Evol 2006; 38: 742-54.

[3 Østvedt OJ. On the life history of the spotted catfish (Anarhichas minor Olafsen). Fiskdir Serie Havunder 1963; 13: 54-72.

[4] Templeman W. Contribution to the Biology of the Spotted Wolffish (Anarhichas minor) in the Northwest Atlantic. J Northwest Atl Fish Sci 1986; 7: 47-55

[5] Falk-Petersen IB, Hansen TK. Early ontogeny of the spotted wolffish (Anarhichas minor Olafsen). Aqua Res 2003; 34: 1059-67. 
[6] Templeman W. Migration of wolffishes, Anarhichas sp., from tagging in the Newfoundland Area. J Northwest Atl Fish Sci 1984; 5: $93-7$.

[7] Barsukov VV. The Wolffish (Anarhichadidae). Fauna SSR Moscow N.S. 1959; 73. (Translated by the Smithsonian Institute 1972).

[8] Reisegg J, Jørstad KE. Stock structure of cod in the Møre area. In: Dahl E, Danielsen DS, Moksness E, Solemdal P, editors. The propagation of cod (Gadus morhua L.) Flødeviken Rapportser 1984; 1: 609-24.

[9] Thomas WK, Beckenbach AT. Variation in salmonid mitochondrial DNA: evolutionary constraints and mechanisms of substitution. J Mol Evol 1989; 29: 233-45.

[10] Gharrett AJ, Gray AK, Heifetz J. Identification of rockfish (Sebastes ssp.) by restriction site analysis of the mitochondrial ND3/ND-4 and 12S/16S rRNA gene region. Fish Bull 2001; 99: 49-62.

[11] Swofford DL, Selander RB.. BIOSYS-2; A Computer program for the analysis of allelic variation in genetics. Department of Genetics and Development, Urbana, Illinois 60801, USA. 1997.

[12] Nei M. Molecular Evolutionary Genetics. Columbia University Press, New York. 1987; pp. 512.

[13] Exoffier L, Laval G, Schneider S. Arlequin Ver 3.01: An integrated software package for population genetics. Evol Bioinform Online 2005; 1: 47-50.

[14] Mantel N. The detection of disease clustering and a generalized regression approach. Cancer Res 1967; 27: 209-220.

[15] Johnson RA, Wichern DW. Applied multivariate statistical analyses. 3rd ed. Prentice-Hall International Editions, Englewood Cliffs, NJ. 1992; 642 pp.

[16] Rice WR. Analysing tables of statistical tests. Evolution 1989; 43: 221-25.

[17] Johansen T, Nævdal G. Genetic analysis of population structure of tusk in the North Atlantic. J Fish Biol 1995; 47: 226-42.

[18] Foss A, Imsland AK, Nævdal G. Population genetic studies of the Atlantic halibut in the North Atlantic Ocean. J Fish Biol 1998; 53: 901-5.

[19] Jónsdóttir ÓDB, Imsland AK, Atladóttir ÓÝ, Daníelsdóttir AK. Nuclear DNA RFLP variation of Atlantic cod in the North Atlantic Ocean. Fish Res 2003; 63: 429-36.
[20] O'Leary DB, Coughlan J, Dillane E, Mccarthy TV, Cross TF. Microsatellite variation in cod Gadus morhua throughout its geographic range. J Fish Biol 2007: 70: 310-35.

[21] Coughlan JP, Imsland AK, Galvin PT, FitzGerald RD, Nævdal G, Cross TF. Microsatellite DNA variation in wild populations. J Fish Biol 1998; 52: 916-922.

[22] Merchand J, Tanguy A, Laroche J, Quiniou L, Maraga D. Responses of European flounder Platichthys flesus populations to contamination in different estuaries along the Atlantic coast of France. Mar Ecol Prog Ser 2003; 260: 273-84.

[23] Hutchison DW, Templeton AR. Correlation of pairwise genetic and geographic distance measures: Inferring the relative influences of gene flow and drift on the distribution of genetic variability. Evolution 1999; 53: 1898-1914.

[24] Crispo E, Hendry AP. Does time since colonization influence isolation by distance? A meta-analysis. Conserv Gen 2005; 6: 665-82.

[25] Castric V, Bernatchez L. The rise and fall of isolation by distance in the anadromous brook charr (Salvelinus fontinalis Mitchill). Genetics 2003; 163: 983-96.

[26] Gold JR, Richardson LR, Turner TF. Temporal stability and spatial divergence of mitochondrial DNA haplotype frequencies in red drum (Sciaenops ocellatus) from coastal regions of the western Atlantic Ocean and Gulf of Mexico. Mar Biol 1999; 133: 593-602.

[27] Hansen B, Ellett D, Meldrum D. Evidence for an anticyclone circulation on Faroe Bank. ICES 1986; CM/C: 15, 15 pp.

[28] Falconer DS.. Introduction to Quantitative Genetics, 3rd edn. Longman, New York 1989; 438 pp.

[29] Anonymous. Wolffish in division 2GHJ, 3KLNO, and subdivision 3Ps/Pn. - DFO Science Stock Status Report: A4-16. Fisheries and Oceans, Canada. ISSN 1480-4913. 2002.

[30] Hansen MM, Loeschcke V. Temporal variation in mitochondrial DNA haplotype frequencies in a brown trout (Salmo trutta L.) population that shows stability in nuclear allele frequencies. Evolution 1996; 50, 454-7.

[31] Larson RJ, Julian RM. Spatial and temporal genetic patchiness in marine populations and their implications for fisheries management. CalCOFI Report 1999; 40: 94-9. 